\title{
Electronic And Spectral Studies of Some Five Coordinate Complexes of Copper (II)
}

\author{
BIRENDRA KUMAR $^{1 *}$, REKHA RANI ${ }^{2}$, DAYANAND PRASAD ${ }^{2}$, \\ PRAVEEN KUMAR SINGH ${ }^{1}$, AMIT KUMAR ${ }^{2}$ and SHIVADHAR SHARMA ${ }^{2}$
}

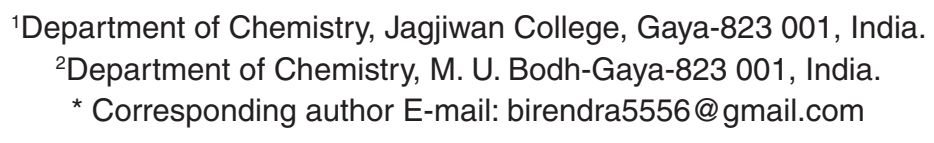

http://dx.doi.org/10.13005/ojc/350430

(Received: June 06, 2019; Accepted: August 16, 2019)

\begin{abstract}
1-phenylazo-2-nephthol has been synthesized and used for complexation with $\mathrm{Cu}$ (II) metal ion along with pyridine, $\alpha$-picoline, $\beta$-picoline, $\gamma$-picoline and water as secondary ligands. On the basis of elemental analysis and molar conductivity complexes were formulated as $\mathrm{CuL}_{2} \mathrm{X}$ [Where $L$ is the prime ligand i.e 1-phenyl-azo-2-nephthol and $X$ is the secondary ligand i.e. pyridine, $\alpha$-picoline, $\beta$-picoline, $\gamma$-picoline and $\mathrm{H}_{2} \mathrm{O}$.] The magnetic moment of these complexes (1.80-1.83 BM) indicates that these complexes are magnetically dilute. The appearance of 3 bands in the electronic spectra of complexes rules out the trigonal bipyramidal $\left(\mathrm{D}_{3} \mathrm{~h}\right)$ symmetry arround $\mathrm{Cu}(\mathrm{II})$ ion in these complexes rather the electronic spectra favours square pyramidal $\left(\mathrm{C}_{4 \mathrm{v}}\right)$ symmetry of these five coordinate complexes. The highest value of $10 \mathrm{Dq}$ clearly indicates the greater coordinating ability of $\alpha$-picoline than pyridine, $\beta$-picoline and $\gamma$-picoline.
\end{abstract}

Keywords: $\alpha$-picoline, $\beta$-picoline, $\gamma$-picoline, trigonal bipyramidal $\left[\mathrm{D}_{3} \mathrm{~h}\right]$, square pyramidal $\left[\mathrm{C}_{4 \mathrm{v}}\right]$, Five coordinate complexes, Magnetically dilute.

\section{INTRODUCTION}

The well known story of blue proteins which have been extensively explored due to their involvement in oxygen and electron transfer in physiological reactions, is well documented ${ }^{1-2}$. Metal ions are electron deficient while most of biological molecules like proteins, DNA, etc, are of these opposing charges leads to a general tendency to form metal ions polymers ${ }^{3-4}$. Chemical nucleaes based on the transition metal ions, cleave DNA hydrolytically or oxydatively with or without added reductant.
$\mathrm{Cu}(\mathrm{II})$ hypyrimol complex $[\mathrm{Cu}(\mathrm{Hypyrimol}) \mathrm{Cl}]$ has been reported to cleave $\varphi \mathrm{X} 174$ supercoiled DNA efficiently without any reductant and also showed high cytotoxicity toward $\mathrm{L}_{1210}$ murine Leukemia and $\mathrm{A}_{2780}$ human, ovarian carcinoma cancer cell lines ${ }^{5-6}$. Riboflavin binding protein responsible for active transport and storage of riboflavin in egg needed for developments also binds $\mathrm{Cu}^{7}$. Dinuclear complexes of copper are also well known artificial metalonucleases and metaloprotenase ${ }^{8}$. Recently superoxide dismutase and antimicrobial activities of emidazolate bridged dinuclear complexes of $\mathrm{Cu}$ (II) have also been reported ${ }^{9}$.

This is an Open Access article licensed under a Creative Commons license: Attribution 4.0 International (CC- BY). Published by Oriental Scientific Publishing Company @ 2018

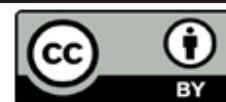


Recently Day et al., ${ }^{10}$ have reported five coordinate $\mathrm{Cu}(\mathrm{II})$ complexes with a N, O donor Schiff-base ligand which showed their effective participation in CT-DNA binding and pBR322 DNA cleavage activities.

The interest in five coordinate complexes took root in 1974 when M. Nonoyama ${ }^{11}$ studied five coordinate $\mathrm{Ni}(\mathrm{II})$ and $\mathrm{Cu}(\mathrm{II})$ complexes and reported their magnetic moments, infrared and electronic spectra.

Albertin et al., ${ }^{12}$ have reported the synthesis and properties of five coordinate $\mathrm{Cu}$ (II) complexes with amine ligand.Milan Melnik et al., ${ }^{13}$ have made a review in 2006 on five coordinate $\mathrm{Cu}$ (II) complexes. The review summarises the data over a good number of four and five coordinate $\mathrm{Cu}$ (II) complexes, mostly with square pyramidal symmetry. The interesting structural features of five coordinate complexes with either square pyramidal or trigonal bipyramidal symmetry invited our attention to five coordinate complexes. In continuation of our previous work $^{14-17}$, in the present paper we report the synthesis and spectral properties of some five coordinate $\mathrm{Cu}$ (II) complexes with 1-phenylazo-2-nephthol (PANH) as prime ligand and $\alpha$-picoline, $\beta$-picoline, $\gamma$-picoline and water as secondary ligand.

\section{MATERIAL AND METHODS}

All the reagents used were of AnalR grade and were used without further purification. Benzene diazonium chloride and 2-nephthol were procured from Marc. India and copper chloride hexa hydrate $\left(\mathrm{CuCl}_{2} \cdot 6 \mathrm{H}_{2} \mathrm{O}\right)$ was purchased from Nice. The ligand 1-phenylazo-2-nephthol (PANH) was prepared by heating the mixture of 0.01 mole $(1.425 \mathrm{~g})$ of benzene diazonium chloride and 0.01 mole $(1.44 \mathrm{~g})$ of 2-nephthol in ethanolic solution for one hour with stirring. On cooling the solution at room temperature, a brown pericipitate appeared which was filtered and washed with alcohol several times. It was recrystallized in alcohol and dried in an electric oven at $90^{\circ} \mathrm{C}$. The yield was found about $80 \%$ and its melting point was recorded $115^{\circ} \mathrm{C}$. The ligand was used for complaxation with $\mathrm{Cu}$ (II) by the usual method of reflux of the ethanolic solution of 0.01 mole of $\mathrm{CuCl}_{2} \cdot 6 \mathrm{H}_{2} \mathrm{O}, 0.02$ mole of PANH and 0.01 of the secondary ligands pyridine or $\alpha$-picoline or $\beta$-picoline or $\gamma$-picoline. Pyridine, $\alpha$-picoline, $\beta$-picoline and $\gamma$-picoline were used as secondary ligand. Complexes were recrystallized in 1:1 ethanol-acetone solvent. The micro analysis of carbon, hydrogen and nitrogen in ligand as well as complexes were carried out by using micro analysis technique on Carbo Erba Micro Analyzer 1108. Copper content in complexes was determined iodometrically. The molar conductivity of the complexes was measured at room temperature with its DMSO solution of $10^{-3} \mathrm{M}$ concentration using Toshniwal digital conductivity meter with deep type cell. The I. R. Spectra of the ligand, 1-phenylazo-2nephthol and its $\mathrm{Cu}(\mathrm{II})$ complexes were recorded on PerkinElomer Model Arc RX1 Spectrophotometer. The magnetic susceptibility of the complexes was measured at room temperature by Gouy's balance using $\mathrm{CuSO}_{4} \cdot 5 \mathrm{H}_{2} \mathrm{O}$ as calibrant. The electronic spectra of complexes were recorded on Perkin-Elmer Lambda 950 Spectrophotometer. The analytical data, magnetic moment and molar conductivity have been presented in Table 1.

Table 1: Percentage Composition (\%) Found/Calculated, Molar Conductivity and Magnetic Moment

\begin{tabular}{|c|c|c|c|c|c|c|c|c|c|}
\hline & Compounds & Colour & m.p. & Metal & C & $\mathrm{H}$ & $\mathrm{N}$ & $\lambda_{\mathrm{m}}\left(\mathrm{Ohm}^{-1} \mathrm{~cm}^{2} \mathrm{~mol}^{-1}\right)$ & $\left.\mu_{s} B M\right)$ \\
\hline 1. & $\begin{array}{l}\text { 1-phenylazo-2- } \\
\text { naphthol(PANH) }\end{array}$ & Brown & $1150 \mathrm{C}$ & -- & $77.64 / 77.42$ & $4.53 / 4.84$ & $11.10 / 11.29$ & -- & -- \\
\hline 2. & {$\left[\mathrm{Cu}(\mathrm{PAN})_{2}\left(\mathrm{H}_{2} \mathrm{O}\right)\right]$} & Green & $259^{\circ} \mathrm{C}$ & $10.96 / 11.03$ & $66.82 / 66.72$ & $4.00 / 4.14$ & $9.61 / 9.73$ & 24 & 2.00 \\
\hline 3. & {$\left[\mathrm{Cu}(\mathrm{PAN})_{2}(\mathrm{Py})\right]$} & Light Green & $265^{\circ} \mathrm{C}$ & $9.81 / 9.98$ & $69.91 / 69.76$ & $4.13 / 4.24$ & $10.84 / 11.00$ & 20 & $1.80 \mathrm{a}$ \\
\hline 4. & {$\left[\mathrm{Cu}(\mathrm{PAN})_{2}(\alpha-\mathrm{PiCO})\right]$} & Light Green & $278^{\circ} \mathrm{C}$ & $9.66 / 9.76$ & $70.30 / 70.10$ & $4.28 / 4.46$ & $10.62 / 10.76$ & 22 & 1.83 \\
\hline 5. & {$\left[\mathrm{Cu}(\mathrm{PAN})_{2}(\beta-\mathrm{PicO})\right]$} & Dull Green & $258^{\circ} \mathrm{C}$ & $9.64 / 9.76$ & $70.35 / 70.10$ & $4.26 / 4.46$ & $10.66 / 10.76$ & 20 & 1.82 \\
\hline 6. & {$\left[\mathrm{Cu}(\mathrm{PAN})_{2}(\Upsilon-\mathrm{Pico})\right]$} & Bright Green & $259^{\circ} \mathrm{C}$ & $9.62 / 9.76$ & $69.32 / 70.10$ & $4.32 / 4.46$ & $10.58 / 10.76$ & 18 & 1.82 \\
\hline
\end{tabular}

\section{RESULT AND DISCUSSION}

The molar conductivity of complexes falls in the range of $18-24 \mathrm{Ohm}^{-1} \mathrm{~cm}^{2} \mathrm{~mol}^{-1}$, which is indicative of non electrolytic nature of complexes ${ }^{18-22}$
On the basis of elemental analytical data and molar conductivity the complexes have been formulated as $\left[\mathrm{Cu}\left(\mathrm{L}_{2}\right) \mathrm{X}\right]$ where $\mathrm{L}$ is 1-phenylazo-2-nephthol $(\mathrm{PANH})$ and $\mathrm{X}$ is $\mathrm{H}_{2} \mathrm{O}$, pyridine, $\alpha$-picoline, $\beta$-picoline and $\gamma$-picoline. Out of cumbersome infrared spectra 
of the free ligand and complexes, some important bands of interest have been discussed here. The IR spectrum of the free ligand displays a broad band at $3200 \mathrm{~cm}^{-1}$ which may be assigned to intramolecular hydrogen bonded phenolic group vibration. ${ }^{23-25}$ The possibility of intramolecular $\mathrm{H}$-Bond formation in the ligand may be seen from its structure.<smiles>NC1=Nc2cc3ccccc3cc2[TlH]1</smiles>

( Five membered ring)

This band disappears in the spectrum of all the complexes of $\mathrm{Cu}(\mathrm{II})$ indicating the deprotonation of phenolic $\mathrm{O}-\mathrm{H}$ group and subsequent coordination through it ${ }^{26-28}$. This supposition is further confirmed by red shift in the absorption frequency of $v_{\text {Ar-C-O }}$ stretching vibration, from $1040 \mathrm{~cm}^{-1}$ in the spectra of free ligand to $1050-1055 \mathrm{~cm}^{-1}$ in the spectra of complexes $^{29-31}$. The bands appearing at $1610 \mathrm{~cm}^{-1}$ (weak and sharp), $1525 \mathrm{~cm}^{-1}$ (strong and sharp) and $1480 \mathrm{~cm}^{-1}$ (medium and sharp) may be assigned to aromatic ring vibration ${ }^{32-33}$. The weak and broad band appearing at $1455 \mathrm{~cm}^{-1}$ in the spectra of free ligands as well as complexes is assigned to the ring vibration of two condensed ring system i.e. naphthalene ${ }^{34-35}$. Thus the presence of both benzene and naphthalene rings in the ligand and complexes is confirmed. A very weak band appearing at $1410 \mathrm{~cm}^{-1}$ in the IR spectra of free ligand has reasonably been assigned to $v_{-\mathrm{N}_{\mathrm{N}-}}$ stretching vibration ${ }^{36}$. This band is found to have undergone blue shifts in the spectra of complexes wherein it absorbs at 1380-1385 $\mathrm{cm}^{-1}$. This negative shifting in stretching vibration of $-\mathrm{N}=\mathrm{N}-($ azo) group is indicative of its involvement in coordination to $\mathrm{Cu}$ (II) in complexes ${ }^{37-38}$. This coordination may further be substantiated by an increase in absorption frequency of $v_{-\mathrm{C}-\mathrm{N}}$ stretching which shifts from $1290 \mathrm{~cm}^{-1}$ in the IR spectrum of free ligand to $1295-1300 \mathrm{~cm}^{-1}$ in the spectra of all the complexes. A tacit support from such proposition may be brought out more clearly from far infrared range wherein two new vibration bands appear in the range of $490-510 \mathrm{~cm}^{-1}$ due to $v_{-\mathrm{Cu}-\mathrm{N}}$ and at $410-420 \mathrm{~cm}^{-1}$ due to $v_{\text {-Cu-O }}{ }^{39-41}$. In addition to these bands some new bands also appear in spectra of complexes.A broad band appearing at $1400 \mathrm{~cm}^{-1}$ with another band at $910 \mathrm{~cm}^{-1}$ are the diagnostic band for coordinated water ${ }^{42-43}$. The appearance of new bands at $755-795 \mathrm{~cm}^{-1}$ is the signature of the presence of coordinated pyridine, $\alpha$-picoline, $\beta$-picoline and $\gamma$-picoline in complexes number 3, 4, 5 and 6 respectively. ${ }^{44-45}$ The graphs of FTIR spectra of the ligand as well as its complexes have been given in Figure 1-5.

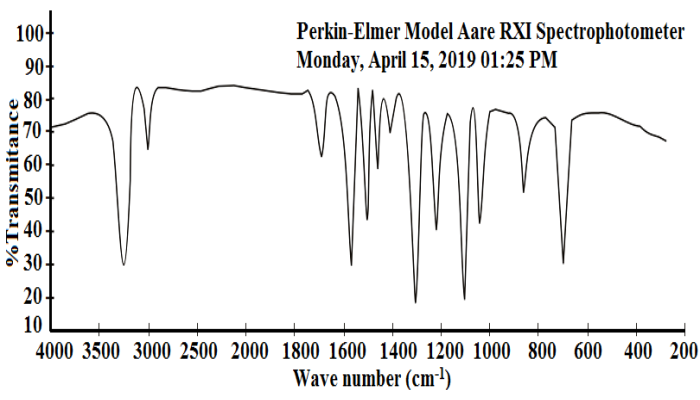

Fig. 1. IR Spectrum of 1-Phenylazo-2-Naphthol, (PNAH)

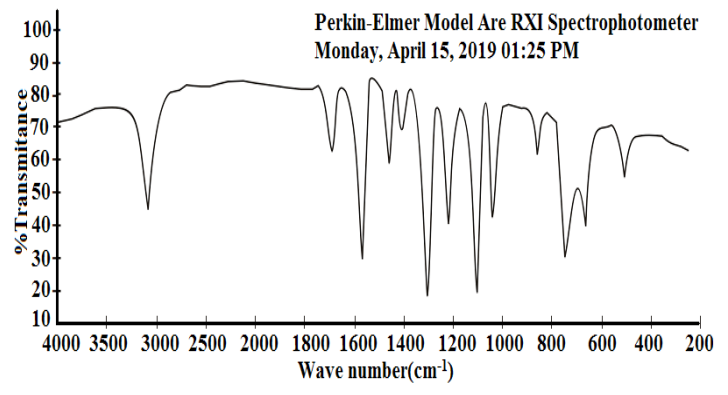

Fig. 2. IR Spectrum of $\mathrm{Cu}(\mathrm{PAN})_{2} \mathrm{Py}$

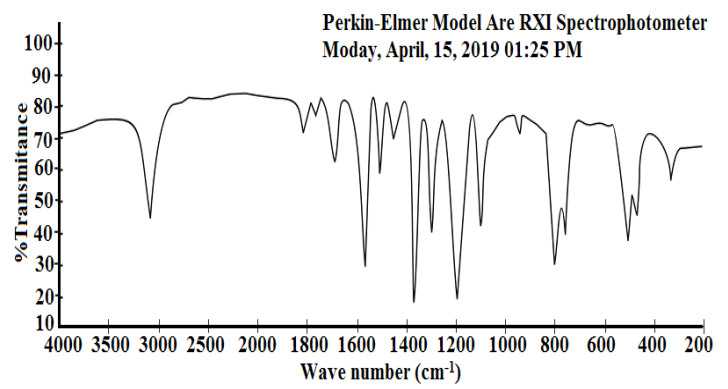

Fig. 3. IR Spectrum of $\mathrm{Cu}(\mathrm{PAN})_{2}(\alpha-\mathrm{Pico})$

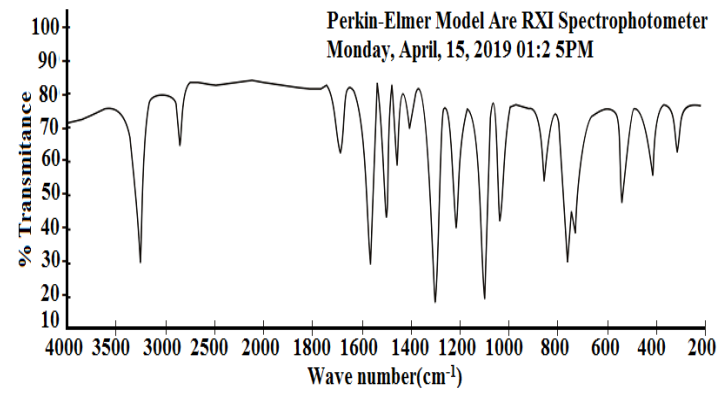

Fig. 4. IR Spectrum of $\mathrm{Cu}(\mathrm{PAN})_{2}(\beta-\mathrm{Pico})$ 


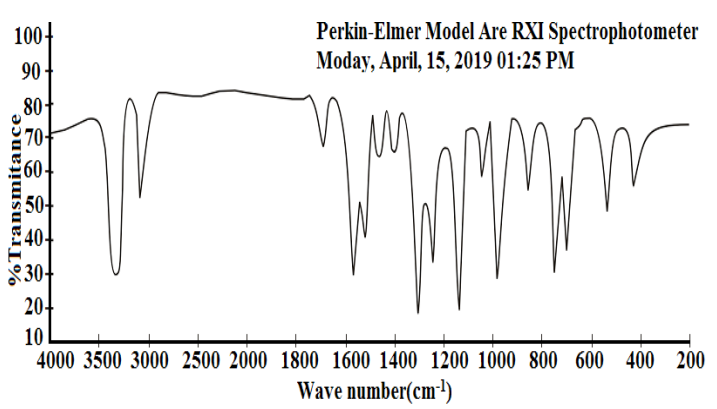

Fig. 5. IR Spectrum of $\mathrm{Cu}(\mathrm{PAN})_{2}\left(\mathrm{H}_{2} \mathrm{O}\right)$

The magnetic moment values of complexes fall in the range of 1.80-2.00BM, which is greater than $\mu_{\mathrm{s}}$ for 1-unpaired electron in $\mathrm{d}^{9}$ System i.e., 1.732BM. It shows that all the complexes are magnetically dilute. The values however couldn't predict the geometry of complexes ${ }^{46-48}$.

From the stoichiometric formula derived from elemental analysis and molar conductivity it may be inferred that $\mathrm{Cu}$ (II) complexes are five coordinated, which may either be of trigonal bipyramidal symmetry $\left(D_{3} h\right)$ or square pyramidal geometry $\left(C_{4 v}\right) \cdot{ }^{49}$ It has been reported that though a trigonal bipyramidal structure is eventually favoured for a five coordinate species, the energy difference between the two is in general rather small. So square pyramidal symmetry for five coordinate complexes may actually be favoured especially when ligands are large and bulki ${ }^{50-51}$.

The other major point to predict the symmetry of a five coordinate complex is that for a complex of $\mathrm{D}_{3 \mathrm{~h}}$ symmetry the electronic spectral bands at 10 , $500-14,600 \mathrm{~cm}^{-1}$ are observed with greater absorption intensity of the lower energy. ${ }^{52-53}$ The five coordinate complexes of $\mathrm{C}_{4 \mathrm{v}}$ symmetry display electronic spectral bands in the range of $11400-15000 \mathrm{~cm}^{-1}$ with greater absorption intensity of the band of higher energy. Secondly the splitting pattern of ${ }^{2} D$-term of $d^{9}$ system. Under the perturbation of $D_{3 h}$ crystal field and $C_{4 v}$ crystal field may be given as below:-

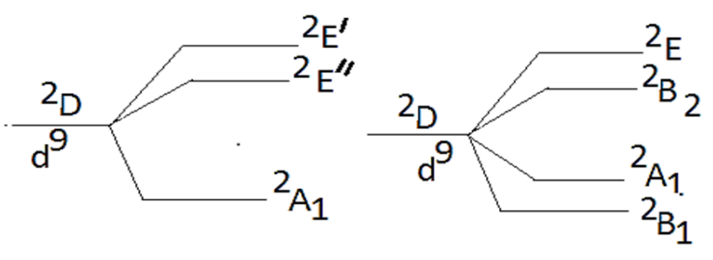

\section{3 h Crystal field $\quad C_{4 v}$ Crystal field}

Thus in the $\mathrm{Cu}(\mathrm{II})$ complexes of $\mathrm{D}_{3 \mathrm{~h}}$ system only two bands are expected while for complexes of $\mathrm{C}_{4 \mathrm{v}}$ symmetry, three bands are expected in their electronic spectra. Here in our study the five coordinate $\mathrm{Cu}$ (II) complexes display three bands in their electronic spectra which are given below in Table 2 with their assignment.

Assignment of these bands may be given as below:-

$v_{1}={ }^{2} \mathrm{~B}_{1} \rightarrow{ }^{2} \mathrm{~A}_{1}$
$v_{2}={ }^{2} \mathrm{~B}_{1} \rightarrow{ }^{2} \mathrm{~B}_{2}$
$v_{3}={ }^{2} \mathrm{~B}_{1} \rightarrow{ }^{2} \mathrm{E}$

Table 2: Electronic spectral band in $\mathrm{cm}^{-1}$

\begin{tabular}{lcccc}
\hline & Compounds & $v_{1}$ & $v_{2}$ & $v_{1}$ \\
\hline 1. & {$\left[\mathrm{Cu}(\text { PAN })_{2}\left(\mathrm{H}_{2} \mathrm{O}\right)\right]$} & 11,580 & 14,250 & 14,700 \\
2. & {$\left[\mathrm{Cu}(\mathrm{PAN})_{2}(\mathrm{Py})\right]$} & 11,500 & 14,000 & 14,800 \\
3. & {$\left[\mathrm{Cu}(\mathrm{PAN})_{2}(\alpha-\mathrm{PiCO})\right]$} & 11,550 & 14,150 & 14,900 \\
4. & {$\left[\mathrm{Cu}(\mathrm{PAN})_{2}(\beta-\mathrm{PiCO})\right]$} & 11,600 & 14,050 & 15,000 \\
5. & {$\left[\mathrm{Cu}(\mathrm{PAN})_{2}(\gamma-\mathrm{PicO})\right]$} & 11,540 & 14,020 & 14,940 \\
\hline
\end{tabular}

Since the $v_{2}$ is the measure of $10 \mathrm{Dq}$. So $10 \mathrm{Dq}$ values of these complexes $\left[\mathrm{Cu}(\mathrm{PAN})_{2}\left(\mathrm{H}_{2} \mathrm{O}\right)\right]$, $\left[\mathrm{Cu}(\mathrm{PAN})_{2}(\mathrm{Py})\right],\left[\mathrm{Cu}(\mathrm{PAN})_{2}(\alpha-\mathrm{PiCO})\right],\left[\mathrm{Cu}(\mathrm{PAN})_{2}\right.$ $(\beta$-Pico) $]$ and $\left[\mathrm{Cu}(\mathrm{PAN})_{2}(\gamma\right.$-Pico)] are $14,250,14,000$, $14,150,14,050$ and $14,020 \mathrm{~cm}^{-1}$ respectively. Since the planner ligand $\mathrm{PANH}$ is the same producing the same crystal field the change in Dq value has been caused by the comparable strength of the ligand along Z-axis. The values are in good arrangement with the values reported for $\mathrm{Cu}$ (II) complexes of square pyramidal geometry ${ }^{54-56}$.

\section{CONCLUSION}

On the basis of the forgoing study of electronic spectra of complexes whole the $\mathrm{Cu}$ (ii) complexes have been found to posses square pyramidal $\left(\mathrm{C}_{4 \mathrm{v}}\right)$ symmetry. The tentative structure is given as below.<smiles>[X]C(Cl)(Cl)N=Nc1cc2ccccc2cc1Oc1cc2ccccc2cc1N=Nc1ccccc1</smiles> 


\section{ACKNOWLEDGEMENT}

The authors are thankful to Dr. R. P. S. Chauhan, Professor and Head. Department of Chemistry, to allowing us the labs at University department of Chemistry and also directing
Technician Dr. Md. Alamgir to record the FTIR and Electronic spectra of complexes.

\section{Conflicts of Interest}

The authors declare no conflict of interest.

\section{REFERENCES}

1. Uhlmann, E.U.; Peymann, A. Chem. Rev., 1990, 90, 543.

2. Sigman, D.S.; Mazumdar, A.; Perkin, D.M. Chem. Rev., 1993, 93, 2295.

3. Schreiber, S.L.; Bioorg. Med. Chem., 1998, $6,1127$.

4. Jemieson, E.R.; Lippard, S. J. Chem. Rev., 1999, 99, 2467.

5. Maheshwari, P. U.; Ray, S.; Dulk, H.; den Barends, S.; Wezel, G.; Van Kozlevcar, B.; Gamez, P.; Reedijik, J. J. Am. Chem. Soc., 2006, 128, 710.

6. Maheshwari, P. U.; Der Ster, M.V.; Smulders, S.; Brends, S.; Wezel, G.; Van. Massera, C.; Roy, S.; Dulk, H. Den.; Gamez, P.; Reedijk, J. J. Inorg. Chem., 2008, 74, 3719.

7. Smith, S. R.; Pala, I.; Parsons, M. B. J. Inorg. Biochem., 2006, 100, 1730.

8. Liu, C.; Wang, M.; Zhang, T.; Sun, H. Coord. Chem. Rev., 2004, 248, 147.

9. Bharti, S.; Chaudhary, M.; Rawat, S. P.; Sangeeta, Noorussabah, Ahmad, K.; Sharma, S. R.; Saket, S.S.; Singh, B.; Das, B.; Kumar, S. J. Indian. Chem. Soc., 2016, 93, 953.

10. Day, D.; Pal, S.;Bag, P.P.; Saha, S.; Chandraleka S.; Dhamsekran, D.; Kole, N.; Biswas, B. J. Ind. Chem. Soc., 2015, 92, 191.

11. Nonoyama, M. Inorg. Chimi. Acta., 1975, 10, 59.

12. Albertin, G.; Bordignon, E.; Orio, A. A. J. Am. Chem. Soc., 1975, 14, 1411.

13. Melnik, M.; Kavesova, M. Dunaj-Jurco, M.; Clive, E.; Holloway, J. Coord. Chem., 2006, 35, 182.

14. Kumar, B.; Kumar, R.; and Kumar, B. Orient. J. Chem., 2015, 31(3), 1827.

15. Kumar, B.; Kumar, B. Kumar, S.; Kumar, D.; and Sharma, S. Orient J. Chem., 2017, 33(5), 2643.

16. Kumari, B.; Kumar, B.; Kumar, S.; Kumar, D.; Sharma, S. Int. J. Engg. Sci. Inv., 2018, 7(5), 14.

17. Kumar, V.; Singh, R. K.; Kumari, V.; Kumar, B.; Sharma, S. Orient. J. Chem., 2018, 34(4), 1937.
18. Kumari, P.; Prakash, S.; Prakash,, D. J. Ind. Chem. Soc., 2012, 89, 19.

19. Rama, I.; Rama Shwami, S. J. Ind. Chem. Soc., 2014, 91, 1877.

20. Kumar, B.; Kumar, B. Kumar, S.; Kumar, D.; and Sharma, S. Orient J. Chem., 2017, 33(5), 2643.

21. Kumari, B.; Kumar, B.; Kumar, S.; Kumar, D.; Sharma, S. Int. J. Engg. Sci. Inv., 2018, 7(5), 14.

22. Kumar, V.; Singh, R. K.; Kumari, V.; Kumar, B.; Sharma, S. Orient. J. Chem., 2018, 34(4), 1937.

23. Rahman, F.; Hiremath, B.; Basava Rajaiah, S. M.; Jaya Kumar Oswamy, B. H. M.; Swami, M. J. Ind. Chem. Soc., 2008, 85, 381.

24. Mahapatra, B. B.; Sarangi, A. K. J. Ind. Chem. Soc., 2009, 86, 559.

25. Kumar, D.; Shayamal, A.; Kumar, A.; Gupta, P. K.; Das, D. J. Ind. Chem. Soc., 2010, 87, 417.

26. Mishra, L. K.; Keshri, B. K. Ind. J. Chem. Sect A., 1981, 28, 863.

27. Singh N. K. and Singh S. B., Ind. J. Chem. Sect A. 1993, 40, 1070.

28. Raman, M.S.; Maninaram, A.; Arunachalan, S.; Krishnan ,C. J.; Chinnuswami, V. J. Ind. Chem. Soc., 2008, 85, 988.

29. Shriniwashan, R.; Verghese.;B.; Sougand, I.; Velaban, K.; Vendkatesan, R.; Rao, P. S. Polyhedran., 2004, 23, 115.

30. Prabhakaran, R.; Krishnan, V.; Karbendu, R.; Geetha, A.; Vertognolli.; Natrajan. K. Inorg. Chem. Acta., 2006, 359, 1114.

31. Das, A. K.; Dev, D.; Bhowmik, K. R. N.; Purkayastha, R. N. D. J. Ind. Chem. Soc., 2009, 86, 76.

32. Thangadurai, T. D.; Gowri, M.; Natrajan, K. Synth. React. Inorg. Metal. Org. Chem., 2002, 32, 329.

33. Singh, M. K.,Laskar, A. D. R.; Paul, B. J. Ind. Chem. Soc., 2008, 85, 485.

34. Nakanishi, K.; "Infrared absorption spectroscopy", Holden Day, Inc. Sanfrancisco and Nankodo company Ltd. Tokyo, Second Printing., 1964, 30. 
35. Chandra, S.; Jain, D.; Sarkar, A.; Anupama. J. Ind. Chem. Soc., 2009, 220.

36. Williams, D. H.; Flemming, I. "Spectroscopic method inorganic Chemistry", TATA Mc Graw Hill Publishing company Ltd. New Delhi, $4^{\text {th }}$ ed. Eighth reprint., 2001, 52-53.

37. Kumaran Nair, M.L.H.; Shyamla, L. J. Ind. Chem. Soc., 2009, 86, 133.

38. Balasubramanian, K.P.; Raju, V.V.; Chinnusamy, V. J. Ind. Chem. Soc., 2009, 86, 570.

39. Ahmad, I.; Akhtar, F. Ind. J. Chem., 1981, 20A, 737.

40. Raman, M. J. Ind. Chem. Soc., 2008, 85, 1082.

41. Krishnankutty, K.; Ummathur, M. D.; Saynder, P. J. Ind. Chem. Soc., 2009, 86, 325.

42. Nakamoto, K. "Infrared spectra of Inorganic and coordination Compounds" , John Wiley and Sons, Inc. New York., 1953, 156.

43. Saha, N.; Dutta, K. N.; Adak, A. K. Ind. J. Chem., 1981, 20A, 744.

44. Albrecht, M. G.; Creghton, J. A. J. Amer. Chem. Soc., 1977, 99, 5215.

45. Yamada, H. Apppl. Spectros. Rev., 1981, 17, 227.
46. Sunatsuki,Y.; Motoda,Y.; Matsumoto, N. Coord. Chem. Rev., 2002, 226, 199.

47. Roth, A.; Becher, J.; Hermann, C.; Gorla, H.; Vaughan, G.; Ritcher, M.; Klemn, D.; Plass, W. Inorg. Chem., 2006, 45, 10066.

48. Mishra, A. P.; Kumar, K. J. Ind. Chem. Soc., 2009, 86, 1150.

49. Mutterties,; Schunn. Quart. Rev. (London)., 1966, 20, 245.

50. Brewster, J. A.; Sarage, C. A.; Venanze. J. Chem. Soc., 1961, 3699.

51. Hertley, J. G.; Verangie, L. M.; Goodall, D. C. J. Chem. Soc., 1963, 4930.

52. Nakamoto, K.; Mc Carthy, P.J., "Spectrocopy and structure of metal chelate compounds", John Wiley and Sons Inc. New York, 1968, 117-122.

53. Bencini, A.; Gatteschi, D. Inorg. Chem., 1977, 16, 1994.

54. Hathaway, B. J.; Billing. Coord. Chem. Rev., 1970, 5, 143.

55. Hitchman, M. A. Inorg. Chem., 1974, 13, 2218.

56. Kumar, B.; Sangal, S. K.; Kumar, A. J. Ind. Chem. Soc., 2009, 86, 1038. 